Proceedings of the 2011 Winter Simulation Conference

S. Jain, R.R. Creasey, J. Himmelspach, K.P. White, and M. Fu, eds.

\title{
SUSTAINABILITY AND SOCIO-ENVIRO-TECHNICAL SYSTEMS: A PROTOTYPE AGENT BASED MODEL TO GENERATE INPUTS FOR COSTING CAPITAL FACILITIES
}

\author{
Kristen L. Sanford Bernhardt \\ Lafayette College \\ Department of Civil \& Environmental Engineering \\ Easton, PA 18042, USA
}

\author{
Annie R. Pearce \\ Virginia Tech \\ Department of Building Construction \\ Blacksburg, VA 24061, USA
}

\author{
Michael J. Garvin \\ Virginia Tech \\ Myers-Lawson School of Construction \\ Blacksburg, VA 24061, USA
}

\begin{abstract}
Public agencies make significant investments in capital facilities to meet the requirements of their missions. Interest in sustainable building practices has increased over recent years, but obstacles remain to implementing such practices in public construction projects on a regular basis. A primary stumbling block is the difficulty in generating accurate estimates for total cost of ownership of a facility in the early stages of design. This paper builds on previously published work to describe the prototype implementation of an agent based model to help determine the inputs for cost modeling.
\end{abstract}

\section{INTRODUCTION}

Public agencies make significant investments in capital facilities to meet the requirements of their missions. For example, the U.S. federal government holds one of the world's largest facilities portfolios with more than 500,000 buildings, structures, and associated infrastructure (NRC 2004). These assets require substantial capital to meet the demands of expansion, the impacts of obsolescence, and the effects of deterioration. Nearly $\$ 40$ billion is spent annually to acquire new federal facilities and to improve, operate and maintain existing ones (NRC 2004). Despite this level of investment, the US General Accounting office listed federal real property management as a government-wide high-risk area in 2003 (GAO 2003). In 2007, GAO issued an update explaining that "progress has been made [on real property], but the problems that led to the designation of federal real property as a high-risk area still exist" (GAO 2007). This general circumstance combined with budgetary and social pressures puts techniques for capital investment decision-making at the forefront of public agency challenges. The addition of political and social forces compelling these agencies to consider the sustainability and lifecycle value of their facilities portfolios only heightens the significance of sound investment decision methods for constructed assets.

Investment in sustainable building technologies and strategies offers the potential for significant lifecycle cost savings over the operational phase of a facility's life and is being actively considered by public sector organizations at the federal, state, and local levels as a way to more effectively meet facility needs within the social and economic constraints faced by these organizations (DuBose, Bosch, and Pearce 2007; USGBC 2003). A growing body of examples suggests that building green need not always cost more initially, particularly if an integrated planning, design, and construction approach is taken (e.g., 


\section{Sanford Bernhardt, Pearce, and Garvin}

Pearce 2008; Hawken, Lovins, and Lovins 1999; Kats 2004). At this point in the evolution of sustainable building practices, however, project planners still have few ways of accurately estimating the first costs of an innovative green project during the early concept development stages, let alone potential lifecycle cost impacts of sustainability.

Tightly coupled integrated design of systems means that investment in better performing and more expensive systems of one type can result in savings in other systems, often substantially offsetting any additional cost associated with the more expensive systems as well as resulting in lifecycle savings (e.g., Pearce 2008; Hawken, Lovins, and Lovins 1999; Kats 2004). The effects of integrated design are difficult to generalize from case to case, however, and challenging to incorporate in preliminary or conceptual estimates for projects where design details are not developed to any degree, as is the case in public sector projects when initial funding requests are being made. Additional public sector institutional practices such as value engineering have the potential to "undo" some of these tight couplings, further impacting not only the initial project budget but also having the potential to create longer term problems and cost impacts if the building no longer performs as designed. Constraints on system types and sources imposed by public sector procurement requirements impose additional challenges that must be considered when evaluating the potential for integrated design in public sector projects, along with the cost impacts it may have. Common practice for estimating sustainable project costs at the conceptual phase is to add a margin to the estimate for a traditional project to cover anticipated increases in design costs, material costs, and other project costs. This approach has the potential to inhibit the implementation of sustainability because (Pearce 2008):

1. projects are typically funded based on efficiency of first cost, meaning that projects with a higher parametric cost estimate are less likely to get funded; and

2. adding a premium to the project estimate means that even if the project is funded, there is reduced incentive to seek cost savings since the money will be lost if it is not spent, thereby creating a self-fulfilling prophecy of increased costs for sustainable projects.

A more strategic approach to investing in sustainability improvement is needed if the public sector is to effectively implement sustainability in its capital projects and avoid setting a precedent and automatic expectation for cost premiums on green projects. Not only must we develop better methods for accurately estimating first costs of sustainable projects vs. their traditional counterparts, but we must also take into account the entire set of costs associated with a project in order to make project decisions that make the best use of public money - we must consider the Total Cost of Ownership (TCO).

The overall challenge faced by public sector owners in increasing the sustainability of their capital project portfolios is to optimize the total cost of ownership of their facilities in light of the services those facilities provide to support their mission. This problem would be challenging enough if all the costs associated with a facility's life cycle were well understood. However, a number of sources of uncertainty exist with respect to life cycle cost that are not well-understood even in conventional facilities, let alone in innovative facilities designed to be more sustainable. Given the long service lives of capital facilities and the continuously evolving missions and needs for those facilities by institutional owners, the uncertainty of future costs increases as the analysis period increases. Table 1 lists some of the uncertainties that should be accounted for in more accurately forecasting total cost of ownership of a facility.

The specific challenge addressed in this work is not the development of new cost models for various phases of the facility life cycle. Rather, the research focuses on being able to predict the inputs that should be fed to existing cost models to obtain cost estimates that more accurately reflect future reality for innovative green capital projects. Being able to identify reasonable inputs is particularly necessary at the very earliest stages of planning innovative projects, when details are not yet known.

\section{MODEL DESCRIPTION}

We have chosen to approach this problem using agent-based modeling (ABM). A much fuller explanation of the motivation for this work, its grounding in the literature, and justification for our approach is 
provided in Pearce, Sanford Bernhardt, and Garvin (2010). This paper describes the prototype implementation of the model.

Table 1: Uncertainties affecting Total Cost of Ownership at the facility scale

\begin{tabular}{|l|l|}
\hline Project Phase & Uncertainties affecting cost \\
\hline Team Formation & Availability of qualified firms in market \\
& Bonding capacity/competition for work \\
& Previous experience of firms with similar projects (risk perception) \\
& Owner comfort/contractibility with unfamiliar firms
\end{tabular}

\subsection{Modeling Environment and Approach}

A variety of tools supporting ABM have become available over the last decade and a half. These tools vary in sophistication and capabilities, as well as required skills for use. For this work, the criteria for tool selection included the ability of the platform to support not only initial modeling efforts but also subsequent expansion to the portfolio scale, and the development of systems for educational purposes and technology transfer. The team also considered the learning curve required for new researchers. After reviewing several alternative implementation platforms, the team chose to work with NetLogo based both on its capabilities and shallower learning curve as compared to other options.

As described in Pearce, Sanford Bernhardt, and Garvin (2010), the project lifecycle was divided into four phases: project team formation, design, construction, and operations. Agents are defined to represent the project owner, designer, constructor, and building components (assemblies). The current version of the model represents the designer and constructor, each of which in reality are teams of professionals, as single agents. Table 2 shows typical agent interactions. The model to date includes modules for team formation and design, as discussed next.

\subsection{Team Formation Module}

In the team formation process, the owner is matched with a designer/contractor pair that meets its criteria. Criteria include the desired level of experience and whether the team should have prior experience with green building technologies; these values are read from a user-created input file. The user inputs information such as the degree to which the owner values green technologies, budget, building size, and the size of the pool of potential designers and contractors. Potential combinations are reviewed for their match with the specified qualifications as well as cost. This process, as implemented in NetLogo, is 
shown in Figure 1. Figure 2 shows the user interface for the combined team formation (Phase I) and design (Phase II) modules. The display box shows the final connection among the owner and the team selected.

Table 2: Various entities are involved in the planning, design, construction, and operations/maintenance (O\&M) of a capital facility during its life cycle (Pearce, Sanford Bernhardt, and Garvin 2010)

\begin{tabular}{|c|c|c|c|c|}
\hline & Team Formation & Design & Construction & O\&M \\
\hline$\sum_{0}^{\grave{d}}$ & $\begin{array}{l}\text { Specifies project need } \\
\text { and feasibility con- } \\
\text { straints; chooses de- } \\
\text { sign/construct entities } \\
\text { for the project from } \\
\text { those circulating in } \\
\text { the market at the time } \\
\text { of selection }\end{array}$ & $\begin{array}{l}\text { Reviews and approves } \\
\text { or rejects system selec- } \\
\text { tion decisions based on } \\
\text { past experience (if any) } \\
\text { with each system }\end{array}$ & $\begin{array}{l}\text { Observes installation } \\
\text { of systems, which in- } \\
\text { fluences experience } \\
\text { with component tech- } \\
\text { nologies for future } \\
\text { projects; approves } \\
\text { substitutions if re- } \\
\text { quired during con- } \\
\text { struction }\end{array}$ & $\begin{array}{l}\text { Interacts with facili- } \\
\text { ty technologies in } \\
\text { ways that result in } \\
\text { operations or } \\
\text { maintenance costs; } \\
\text { adjusts opinions of } \\
\text { components that will } \\
\text { influence selection } \\
\text { on future projects }\end{array}$ \\
\hline$\frac{\bar{d}}{\stackrel{0}{0}}$ & $\begin{array}{l}\text { Responds to relevant } \\
\text { project opportunities } \\
\text { as long as capacity ex- } \\
\text { ists; selection attrib- } \\
\text { utes include design } \\
\text { philosophy and past } \\
\text { experience with simi- } \\
\text { lar projects }\end{array}$ & $\begin{array}{l}\text { Develops configura- } \\
\text { tions of building sys- } \\
\text { tems to improve upon } \\
\text { prototype design sup- } \\
\text { plied by owner; influ- } \\
\text { ences these configura- } \\
\text { tions based on past } \\
\text { experiences with com- } \\
\text { ponent systems }\end{array}$ & $\begin{array}{l}\text { Observes installation } \\
\text { of systems, which in- } \\
\text { fluences experience } \\
\text { with component tech- } \\
\text { nologies for future } \\
\text { projects; supplies sub- } \\
\text { stitutions if required } \\
\text { during construction }\end{array}$ & $\begin{array}{l}\text { Not involved except } \\
\text { for possible feed- } \\
\text { back on systems } \\
\text { performance and } \\
\text { client satisfaction } \\
\text { with design deci- } \\
\text { sions }\end{array}$ \\
\hline 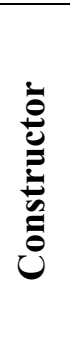 & $\begin{array}{l}\text { Responds to relevant } \\
\text { project opportunities } \\
\text { as long as capacity ex- } \\
\text { ists; selection attrib- } \\
\text { utes includes past ex- } \\
\text { perience with similar } \\
\text { projects }\end{array}$ & $\begin{array}{l}\text { Supplies price infor- } \\
\text { mation for design sce- } \\
\text { narios based on prior } \\
\text { experience and market } \\
\text { conditions }\end{array}$ & $\begin{array}{l}\text { Coordinates installa- } \\
\text { tion of systems using } \\
\text { subcontractor and } \\
\text { supplier agents; costs } \\
\text { based on market con- } \\
\text { dition and prior expe- } \\
\text { rience with each com- } \\
\text { ponent type }\end{array}$ & $\begin{array}{l}\text { Limited involve- } \\
\text { ment for callbacks } \\
\text { to handle warranty } \\
\text { issues; no influence } \\
\text { on cost }\end{array}$ \\
\hline 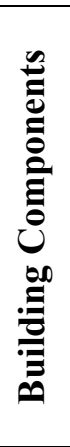 & $\begin{array}{l}\text { Not involved unless } \\
\text { modeling resource } \\
\text { scarcity issues in the } \\
\text { market }\end{array}$ & $\begin{array}{l}\text { Gravitate toward or } \\
\text { away from prototype } \\
\text { design within decision } \\
\text { space; are either reject- } \\
\text { ed or incorporated } \\
\text { based on whether they } \\
\text { can improve perfor- } \\
\text { mance and "greenness" } \\
\text { without violating con- } \\
\text { straints }\end{array}$ & $\begin{array}{l}\text { Pair with subcontrac- } \\
\text { tor and supplier agents } \\
\text { to be procured and in- } \\
\text { stalled on project, sub- } \\
\text { ject to market con- } \\
\text { straints; may provide } \\
\text { a positive or negative } \\
\text { experience for associ- } \\
\text { ated agents }\end{array}$ & $\begin{array}{l}\text { Interact with own- } \\
\text { er/user agents to re- } \\
\text { sult in operations } \\
\text { and maintenance } \\
\text { costs such as energy } \\
\text { use, water use, com- } \\
\text { ponent repair and } \\
\text { replacement, etc. }\end{array}$ \\
\hline
\end{tabular}

\subsection{Design Module}

The design module works much as described in Pearce, Sanford Bernhardt, and Garvin (2010). A prototype building is created that includes "slots" (in NetLogo, these are patches) for each required building assembly type. Each slot is filled with a prototype assembly based on conventional building technologies. Each assembly has associated with it a unit cost and "greenness," which represents a sustainability metric. 
The prototype building stores the square footage, which is input by the user through the user interface. Other items determined through the user interface include the project climate, LEED goal, and life expectancy, as well as the user-defined interest rate to be used in lifecycle cost calculations.

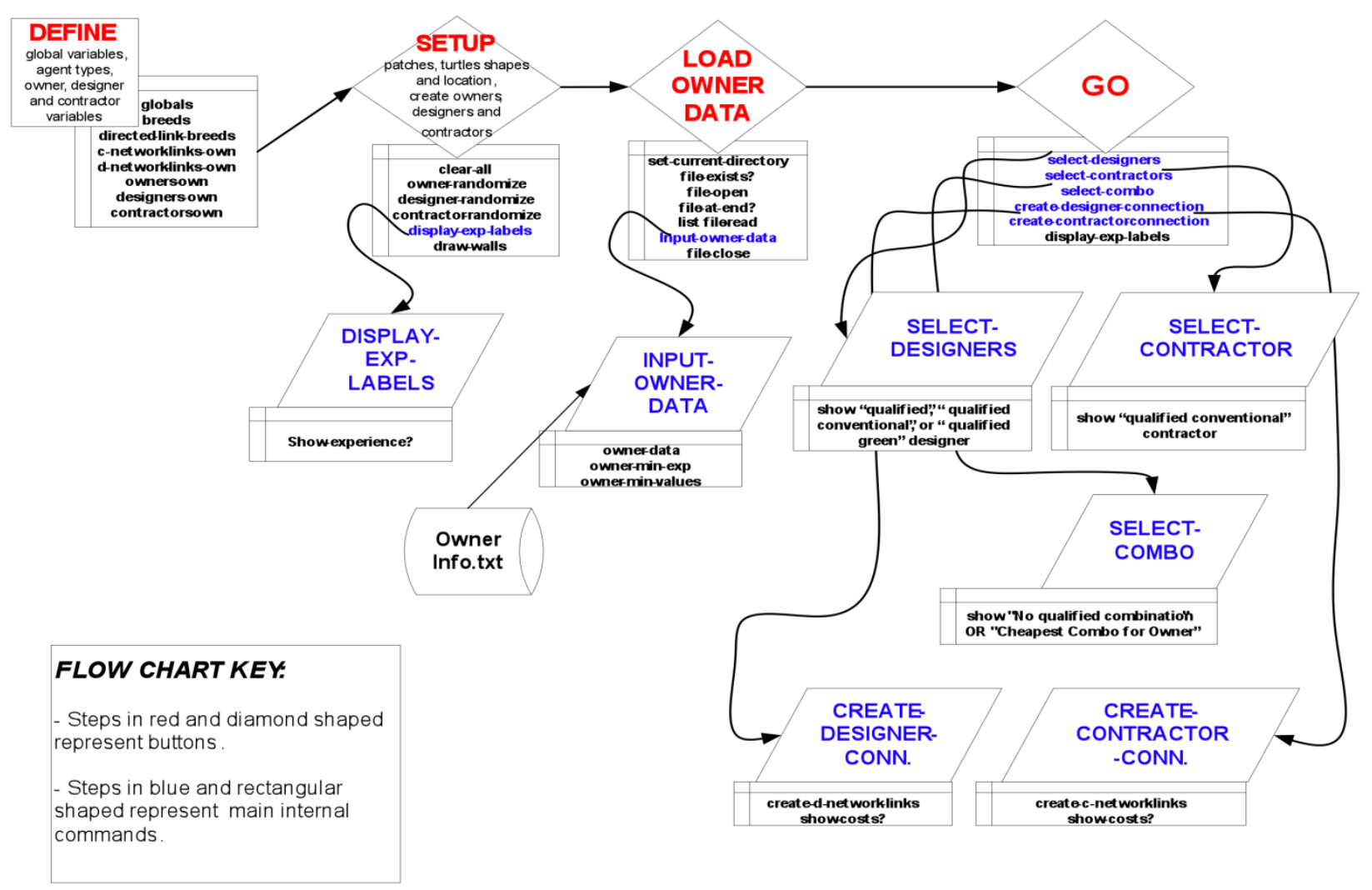

Figure 1: Flow diagram for forming project teams

A data set of alternative assemblies with corresponding cost and sustainability data are input through a user-defined text file. In the simulation, alternative assemblies move toward the prototype at varying speeds based on their appropriateness for the project. When an alternative assembly reaches the prototype, it is compared to determine whether it is the same assembly type. If the type matches, and its unit cost is lower and/or it is more sustainable, the alternative assembly temporarily replaces the prototype assembly so that a lifecycle cost can be calculated. Figure 3 shows the sequence of actions for the coding in Netlogo.

The contribution of the particular type of assembly to the overall project's sustainability could be operationalized in multiple ways, but in this project, potential assemblies are pre-assigned values for sustainability ("greenness") based on their potential for resource conservation, reduction of ecosystem impact, or improvement of environmental quality. If the cost is within tolerance levels set by the owner, the replacement becomes permanent; otherwise, the original assembly is recalled to its original position in the prototype. This process continues until the total cost stabilizes.

Figure 4 shows the interaction among assemblies in the Design Module (Phase II). In the upper box, the turtles in the shape of the tanks represent the prototype assemblies and the flying saucer shaped turtles represent the alternative assemblies. The assemblies surround the design team and the building. These are the selected prototype and alternative assemblies that are used to calculate the TCO. The bottom box graphs the total cost of ownership - when an assembly is replaced, the cost changes. 


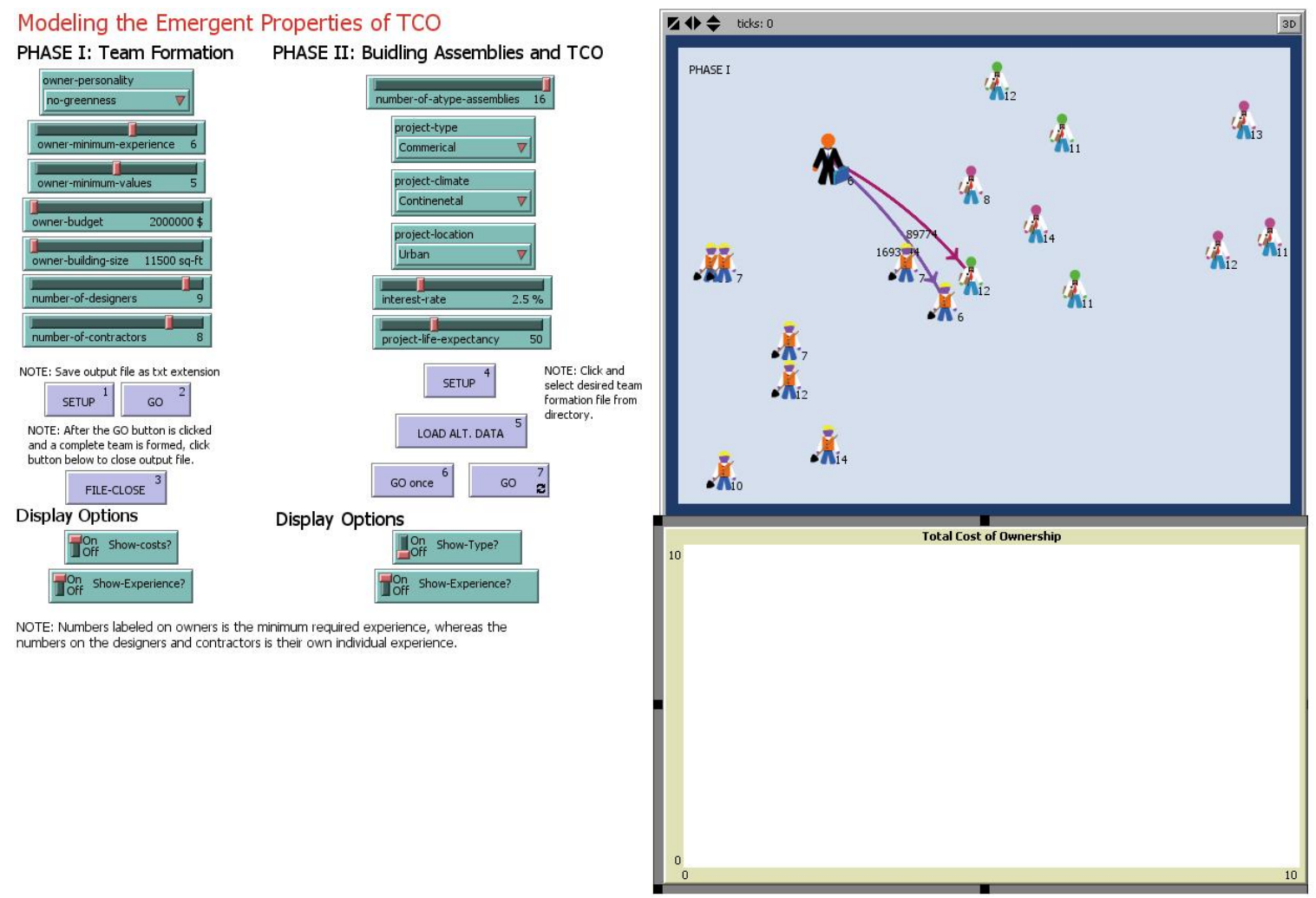

Figure 2: Screen shot of combined project team formation and design modules

\section{SUMMARY, CONCLUSIONS, AND NEXT STEPS}

The implementation work described to date has demonstrated the viability of the modeling approach described in Pearce, Sanford Bernhardt, and Garvin (2010). Significant work remains to add to the sophistication of the model in terms of procedure and user interface. The agent-based modeling approach used here provides the modularity and flexibility necessary to develop new aspects of organizational and individual behavior based on additional research, and to refine existing characterizations over time.

The way in which data is represented in the prototype model affords considerable opportunities for increasing the sophistication and fidelity of the model with respect to the socio-enviro-technical system it represents. For example, in the current model, information about system costs is captured as static data developed from external cost models and included as an attribute of each of the agents representing facility systems in the design phase. The prototype model and the cost models providing data are not interoperable at this point in the research, although automating this connection could increase the richness of the cost representation by allowing the agent-based model to drive a cost estimate of the whole integrated design with each model iteration. Similarly, establishing interoperability with life cycle costing models or even component models for energy performance of a facility would allow the attributes of each agent to more accurately reflect the whole system instead of a static approximation. As models of facility LEED performance and sustainability continue to evolve in the Building Information Modeling domain, they could also be used to change the prototype's static representation of an assembly's contribution to project sustainability to a more dynamic reflection of its function within the overall project as a whole.

In parallel to development of the prototype model, work has also continued on identifying and refining descriptions of stakeholder behaviors and interactions through document analysis and interviews, with field observations ongoing as part of further research for validation. Immediate model validation is presently underway using data from the U.S. Postal Service for a series of post offices developed using the 
USPS's prototype post office design. One such facility has been extensively modeled with a variety of energy performance improvements (Ahn 2010) and is being used to test the validity of the design module of the ABM model.

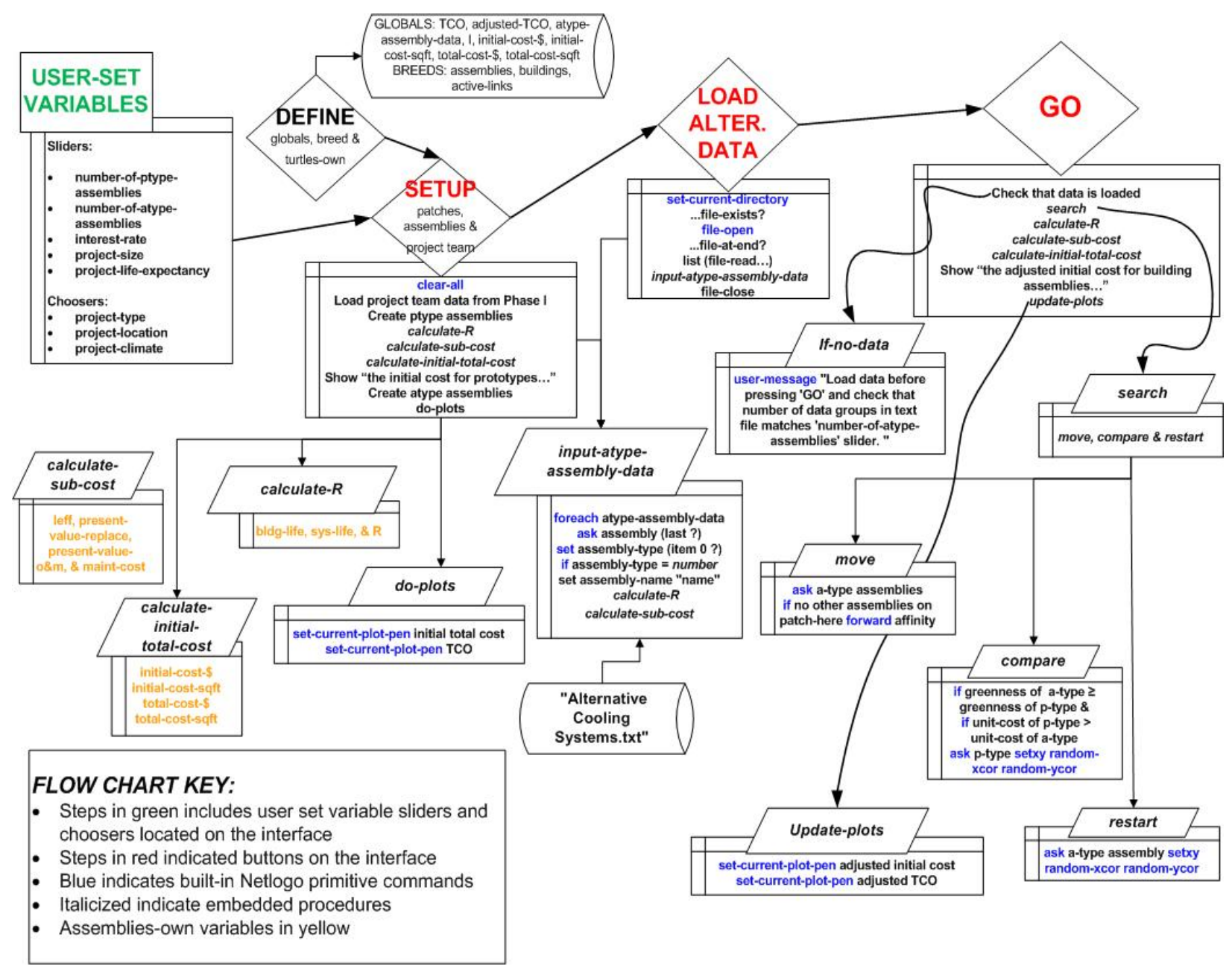

Figure 3: Flow diagram for assembly replacement and TCO calculations

In addition to continuing model development and evaluation, the research team plans to develop the prototype model into an educational simulation game and module to be used by middle school, high school, and university students as a means to learn about sustainability, decision making, and construction projects and facilities. This educational module will be publicly available from the Engineering Pathways Database (http://www.engineeringpathways.org). It will be usable as part of engineering and sciencerelated courses to increase students' awareness of the complexity of decision making for project planning as well as to provide opportunities to expose students to thinking about sustainable design and construction concepts in practice. 


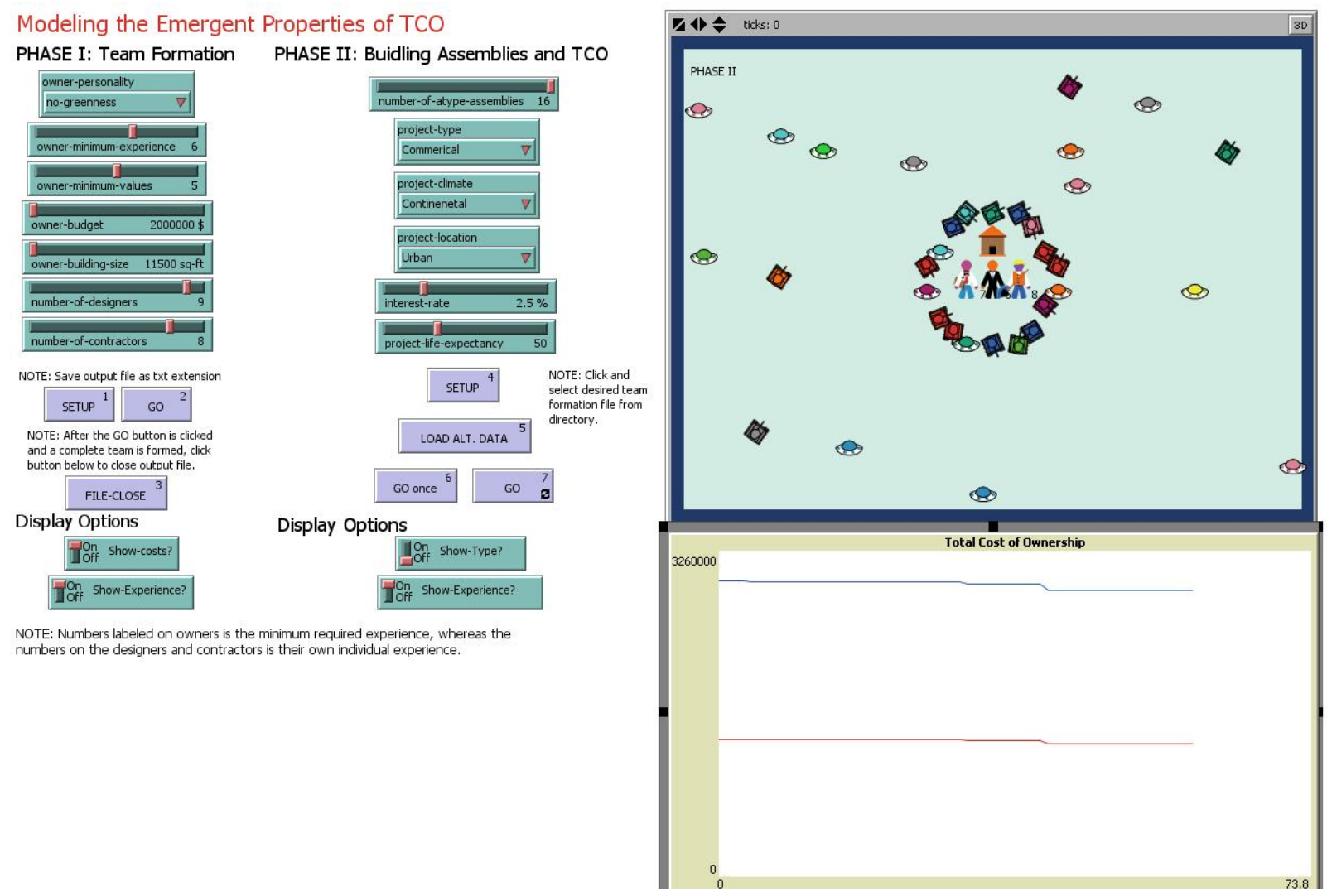

Figure 4: Screen shot of prototype and alternative assemblies in the decision space during Phase II

\section{ACKNOWLEDGMENTS}

This research was supported by National Science Foundation Grant 0828779: "Sustainability and Capital Project Portfolios: Modeling the Emergent Property of Total Cost of Ownership." Any opinions, findings, conclusions, or recommendations expressed in this paper are those of the authors and do not necessarily reflect the views of the National Science Foundation. The authors thank the many students who have contributed to this project to date, including Sushil Shenoy, Adam Hise, Yong Han Ahn, Sandeep Langar, and Chayanika Mitra (Virginia Tech), and Abseen Anya, Mosi London, Cara Lyons, Peter Mara, and Stephanie Mason (Lafayette).

\section{REFERENCES}

Ahn, Y. H. 2010. "Sustainability Investments for Capital Project Portfolios.” Ph.D. Dissertation, Environmental Design and Planning, Virginia Polytechnic Institute and State University, Blacksburg, VA.

DuBose, J. R., S. J. Bosch, and A. R. Pearce. 2007. "Analysis of Statewide Green Building Policies." Journal of Green Building 2(2):161-177.

GAO (General Accounting Office). 2003. High Risk Series: Federal Real Property. Washington, D.C.: GAO.

GAO (General Accounting Office). 2007. High Risk Series: An Update. Washington, D.C.: GAO.

Hawken, P., A. B. Lovins, and L. H. Lovins. 1999. Natural Capitalism. Boston, MA: Little, Brown, \& Co.

Kats, G. H. 2004. "Green Building Costs and Financial Benefits." Report to California's Sustainable Building Task Force, Capital E (www.cap-e.com). 
NRC (National Research Council). 2004. Investments in Federal Facilities: Asset Management Strategies for the $21^{\text {st }}$ Century. Washington, D.C.: National Academies Press.

Pearce, A. R. 2008. "Sustainable Capital Projects: Leapfrogging the First Cost Barrier." Civil Engineering and Environmental Systems 25(4):291-301.

Pearce, A. R., K. L. Sanford Bernhardt, and M. J. Garvin. 2010. "Sustainability and Socio-envirotechnical Systems: Modeling Total Cost of Ownership in Capital Facilities." In Proceedings of the 2010 Winter Simulation Conference, edited by B. Johansson, S. Jain, J. Montoya-Torres, J. Hugan, and E. Yücesan, 3157-3169. Piscataway, New Jersey: Institute of Electrical and Electronics Engineers, Inc.

USGBC (U.S. Green Building Council). 2003. Building Momentum: National Trends and Prospects for High-Performance. Washington, DC: U.S. Green Building Council.

\section{AUTHOR BIOGRAPHIES}

KRISTEN L. SANFORD BERNHARDT is an Associate Professor in the Department of Civil \& Environmental Engineering and Chair of the Engineering Studies Program at Lafayette College. Her research interests are in the general areas of sustainable civil infrastructure management and transportation systems, with particular emphasis on data requirements, decision support, and applications of new technology. She received her Ph.D. and M.S. from Carnegie Mellon University, and her B.S.E. from Duke University, all in Civil and Environmental Engineering. Her email address is sanfordk@lafayette.edu.

ANNIE R. PEARCE is an Associate Professor in the Department of Building Construction, MyersLawson School of Construction at Virginia Tech specializing in sustainable facilities and infrastructure systems. Her specific areas of interest include metrics of sustainability for built facilities, green building materials and systems, cost modeling to support sustainability implementation, and in situ performance of sustainable facility technologies. She has a B.S. Civil Engineering from Carnegie Mellon, and M.S. and Ph.D. Civil Engineering from Georgia Tech. Her email address is apearce@vt.edu.

MICHAEL J. GARVIN is an Associate Professor in the Myers-Lawson School of Construction at Virginia Tech. His research and teaching focuses on the programming, financing, and delivery of large-scale infrastructure projects. He has a particular interest in the structure and effectiveness of infrastructure public-private partnerships. He received a B.S. Civil Engineering from the United States Military Academy and MS and $\mathrm{PhD}$ degrees from the Massachusetts Institute of Technology. His email address is garvin@vt.edu. 